\title{
The Validity and Challenges of the Traditional Chieftaincy in Modern Decentralization or Decentralized Governance for Development (DGD) In Lesotho
}

\author{
Moses M. M. Daemane \\ National University of Lesotho, Lesotho \\ mosesdaemane@gmail.com
}

\begin{abstract}
This is a public management policy system or development administration exploring paper on the country of Lesotho. It is a desk study reviewing the validity of an argument justifying the role of the traditional rule or chieftaincy in the modern 'decentralized governance for development' (DGD) or decentralization in Lesotho. The paper discusses chieftaincy and colonialism in Lesotho, institutional roles of chieftaincy, the role of chieftaincy in the era of modern democracy/DGD, the relations between the democratic local authorities and chieftaincy in Lesotho and the role of chieftaincy and its constraints in the decentralized system of Lesotho. The paper directly contributes knowledge in public management sciences and administrative policy systems.
\end{abstract}

Keywords: Decentralization, Decentralized Governance for Development (DGD), Chieftaincy, Democracy, Local authorities, Lesotho

\section{Introduction}

The aim of this desk study is to review the validity of an argument justifying the role of the traditional rule or chieftaincy in the modern 'decentralized governance for development' (DGD) or decentralization in Lesotho. The question addressed in here is what is the role of traditional chieftaincy in the modern era of Lesotho's democracy/DGD? What are the function of traditional chieftaincy and its nature of relations with the democratic local authorities and constraints in DGD in Lesotho? Firstly, the article discusses chieftaincy and colonialism in Lesotho, secondly, institutional roles of chieftaincy in Lesotho, thirdly, the role of chieftaincy in the era of democracy/DGD in Lesotho, fourthly, nature of relations between the democratic local authorities and chieftaincy in Lesotho and lastly the role of chieftaincy and its constraints in the decentralized system of Lesotho. The rationale for this article is to add both practical and theoretical knowledge/expertise in public management policy system or development administration through exploring the country of Lesotho on these very aspects. This desk study reviews the validity of an argument justifying the role of the traditional rule or chieftaincy in the modern 'decentralized governance for development' (DGD) or decentralization in Lesotho. The paper directly contributes knowledge in public management sciences and administrative policy systems.

Lesotho is a parliamentary constitutional monarchy state. The executive powers belong to the democratically constituted parliament. The country's system of governance follows a two-tier structure. The one tier is chieftainship and the other tier consists of democratically elected representatives some of whom are appointed as the executive members. The parliament is made up of two houses, the Senate/Upper House and the National Assembly/Lower House. The Prime Minister is the (political) head of the government while the King is the (neutral-symbol of national unity) head of the state. The Prime Minister is appointed from the political party with more seats in the parliament. Most of the Ministers are appointed from the National Assembly and the few from the Senate. Some of the Ministers are then appointed to form the ruling cabinet. The Senate is made up of twenty two principal chiefs (mainly of the Bakuena ('crocodile clan') lineage belonging to the 'Mokoteli' royal family) and two (in-laws to the former) other independent chiefs from other 'Sotho' popularly dominant lineages and nine other people appointed by the King as advised by the State Council and the Prime Minister. The monarch system is in such a way that (22) principal chiefs rule over wards, (1200) customary chiefs under the principal chiefs look after demarcated areas in the ward with the help of (506) village chiefs/headmen in the communities. Lesotho has adopted mixed member proportional model (MMP) before the 2002 general elections. This combined the first past the post (FPP) and proportional representation (PR) systems. The change from pure FPP was prompted by the 1998 political riots over its 
exclusiveness in that other parties saw the only one party taking all the seats to have rigged the elections. The riots of 1998 caused damage on property worth of more than USD200 million. The Southern African Development Community (SADC) had to intervene militarily using armed forces from the Republic of Botswana and South Africa. The National Assembly consists of 120 elected members, 80 of those through FPP model while 40 are elected through PR model. The senate scrutinizes the bills from the lower house though this may be bypassed for a royal assent for law making.

This structurally puts chieftaincy as a legal delaying procedural opposition to democratic reforms and creates a power struggle between the houses, Parliament seeking expedient reforms, Senate chieftaincy remaining conservative. The Parliament deems the Senate as undemocratic and not elected by the people and therefore representing no body, having no mandate. The Senate perceives the Parliament as 'bochaba-sere'/the public says-people who are pursuing their own political agenda of demolishing chieftaincy and Basotho traditions. Decentralization as one political institutional reform for local democratic governance has to take place in societies that have had their traditional ways of self-governing. Such a traditional way with the longest history is cultural institutional lineage leadership called chieftaincy. Before the influential winds of colonialism, democracy and globalization this structural form of leadership used to take the responsibilities almost equivalent to that one of the government but in the traditional communistic-collective industrious way of rule involving mainly a male-elderly consultative style and traditional patriarchal autocracy rather than a very clear capitalistic individualistic democratic mode of life. Chieftaincy as traditional authorities therefore poses many challenges to DGD. These difficult challenges at times tend to be a conflict and competition over any form of power over resources, policy and the communities. This article is about unearthing these challenges that stand in the way of DGD and realizing the validity of the role of chieftaincy as that may help consolidate the success of decentralization and prosperity of the local communities in Lesotho. Now traditional chieftaincy is integrated into the 'modern' democratic structures of DGD as shown on the table below:

Table 1: Composition of Community Councils/CCs and Representation of Chiefs in them

\begin{tabular}{lllllll}
\hline District & $\begin{array}{l}\text { Chiefs in } \\
\text { Community } \\
\text { Councils }\end{array}$ & \multicolumn{2}{l}{$\begin{array}{l}\text { Composition } \\
\text { Councilors/CCs including Chiefs }\end{array}$} & $\begin{array}{c}\text { Of } \\
\text { Community District } \\
\text { Councilors/DCs }\end{array}$ & $\begin{array}{l}\text { Chiefs in District } \\
\text { Councils }\end{array}$ \\
\hline Leribe & 36 & Total & Male & Female & & \\
Berea & 19 & 124 & 79 & 99 & 38 & 2 \\
Mafeteng & 24 & 142 & 58 & 60 & 22 & 2 \\
Mohale's Hoek & 27 & 172 & 71 & 74 & 30 & 2 \\
Quthing & 20 & 124 & 51 & 53 & 22 & 2 \\
Qacha's Nek & 20 & 123 & 47 & 56 & 23 & 2 \\
Mokhotiong & 30 & 184 & 74 & 80 & 32 & 2 \\
Thaba Tseka & 23 & 149 & 63 & 63 & 28 & 2 \\
Botha Bothe & 20 & 114 & 44 & 52 & 23 & 2 \\
Maseru & 30 & 177 & 68 & 82 & 33 & 276 \\
Totals & $\mathbf{2 4 9}$ & $\mathbf{1 5 0 8}$ & $\mathbf{6 1 2}$ & $\mathbf{6 7 9}$ & $\mathbf{2 7 6}$ & 2 \\
\hline
\end{tabular}

Source: GoL Reports, 2006 and 2009.

The Validity of an Argument Justifying the Role of the Traditional Chieftaincy in modern Decentralized Governance for Development/DGD: In the light of the fact that before the advent of colonialism societies traditionally locally governed themselves through traditional rulers or chieftaincy, the relevance and the legacy of this is still justified even in the modern DGD era. Lesotho was one of the British protectorates, which has had traditional leadership before the colonial era, continued to preserve and practice this chieftaincy during and after the colonial era. The British colonial impact on this leadership has 
not been exceptional in Lesotho. The question then remains in this context, does Lesotho really still need this chieftaincy if it tends out to be a formidable structural threat and challenge for power struggle. Reviewing the related literature in this light could help clear the mist between chieftaincy and decentralization in Lesotho. First of all, Miles (1993) argues that though paramountcy of chieftaincy was undone by colonial rule, it served as important adjuncts (add-on) in the administration of post-colonial government in both Africa and Oceania. He argues that chieftaincy is an agent of administration on which governments have all come to rely on its assistance in development activities. He describes chieftaincy as traditional pre-independence governance. Its 5 modern functions in DGD are (1) linkage/'brokering' between grassroots and capital, (2) extension of national identity through the conferral of traditional titles,(3) low-level conflict resolution and judicial (legal) gate-keeping. (4) Ombudsmanship, (5) institutional safety-valve for overloaded and sub- apportioned bureaucracies in DGD. He also argues that creation of educated chieftaincy significantly enhances its effectiveness in contributing in DGD thus educating traditional leadership translates it to relevant helpful backing administration in decentralization.

It has been recognized that Western models of administration and socio-economic change are not perfect models for the developing societies, whether it be mixed government and dual authority. Traditional modes of governance need to be recognized for effective administration on the part of national governments. In Africa, mobilization (sometimes demobilization) of chieftaincy by governments acceding to independence has reflected colonial patterns previously established by European powers. The classic contrast is between the French the British. For example, the French incorporated pliable chiefs into their own bureaucracy, strictly as executioners of French administrative policy or appoint non-royals who demonstrated loyalty to the French cause by prior service where such chieftaincy lacked. However, the British conferred greater autonomy (sometimes bolstering/boosting it) to chieftaincy within their colonies including Lesotho. Stricter adherence to traditional norms of chiefly accession was practiced. Resultantly chieftaincy under British colonial rule emerged at independence with greater power and authority vis-à-vis national government that did counterparts in former French territory. France and Britain had different ideas about how local government should be established. Overall retention of chieftaincy and its use as an agent of governance was agreeable to both powers but how much authority should this indigenous institution be granted remained an ambiguous issue. French suspected chieftaincy to be seeking independence before it is ready to accord it (Esman, 1988 and Miles, 1993).

\section{Chieftaincy and Colonialism}

As colonial era began winding down, pro-independence forces criticised chieftaincy for its accommodationist if not collaborationist policy toward European overlords. This was an unfair criticism in that chieftaincy tried and continued to try in vain to prevent British and French domination. However, anti- chieftaincy criticism had an even deeper source. Pro-independence politicians viewed chieftaincy as an anachronistic, retrograde or reactionary force with no place in the upcoming 'new' independent Africa (with new institutions, new leaders, and new mentality). Thus, chieftaincy was not considered as a serious instrument for progress, development or national unity. Other former British colonies tried or even succeeded to abolish chieftaincy (Tanzania, Sierra Leone). Some former colonies just expected chieftaincy to continue owing loyalty to rulers of the colony-turned-nation unquestionably, as under colonialism, what differed was just the degree of such loyalty. Regardless of individual failures, chieftaincy represented a comfortable image of stability, continuity and familiarity. As an institution, chieftaincy also suffered more from neglect through colonial nonrecognition than any deliberate anti-chieftaincy policy. In some regions, the French and British just appointed trusted 'assessors' as authorities to bypass chieftaincy. Assessors acted as intermediaries between locals and colonial authorities. Assessor's resolved minor disputes referred more serious (statutory crimes) to colonial District Agent. They also provided advice to the colonial agents on sentencing, all which was supposed to be done by excluded chieftaincy. Resultantly in such regions, chieftaincy became discarded in traditional customary life providing other justification grounds by pro-independence movements but without clear ideal role in modern times (Esman, 1988 and Miles, 1993).

Institutional Roles of Chieftaincy: In the run-up to independence, colonial authorities envisioned a continuing role for chieftaincy after their departure. This was so despite assumption of all democratically elected postcolonial governments. Chieftaincy thus retained control of local government as head of the Native 
Authority/later Native Administrative structure. Royalty were often elected to respective Houses of Assembly, and to the national House of Assembly though were not guaranteed representation at these levels. Some countries introduced the House of Chiefs with more powers but with some equivalence to the British House of Lords. Military coups and constitutional changes reduced powers of chieftaincy at local levels introducing elected leadership (e.g. chairmanship of councils), native authorities/traditional authorities with reduced powers with basic functions like advisory to local government and government in general, responsibility for tax collection, religious matters, customary law, arts and culture and chieftaincy matters. As a result, chieftaincy lacked executive power and remained periodically lobbying for more powers. By the end of the colonial era, in French colonies chieftaincy was relied upon as the best counterweight to more radical progressive nationalist leaders despite the initial strategy of 'crush and destroy'. France had no chiefs and understood postcolonial administration and government to be modelled on the metropolitan model. Thus, French colonialists put little stock on chieftaincy and its associations as an authoritative group (Miles, 1993). However, chieftaincy represented a utilitarian institution whose worth lay in its contribution to nation's development efforts. Other than parties and military inspiring more fear, it enthusiastically remained the most viable mechanism for directing and mobilizing the masses thus providing linkage function between the policymakers in capital and villagers throughout countryside for non-democratic development. Oftentimes when electoral democracy/multi-party system developed, chieftaincy experienced under representation and difficult proper role redefining moment as it condoned non-egalitarianism during colonialism (Esman, 1988 and Miles, 1993).

\section{The Role of Chieftaincy in the Era of Democracy/DGD}

In this era of global democratization, chieftaincy as a symbol of pre-modern politics and non-democratic governance, may still serve as a valuable adjunct to the process of development.

Linkage Role: ('middleman' or 'broker' role) chieftaincy is instrumental in serving as intermediaries between government and populace.

- Chieftaincy relates with national government on advisory and balanced level but sometimes in other places in a directive and coercive manner by governments.

- Government leaders rely more and more on chieftaincy for as the appropriate mechanism for nonpartisan popular exchange.

- It is incumbent upon chieftaincy to educate masses as to the direction of government developmental policy regardless of whether the system is egalitarian or authoritarian.

- The linkage function is generally performed in two ways at grassroots level, firstly, is the direct convocation of local chiefs by representatives of the national and/or local government. Secondly, it is convocation at national level followed by information dissemination down the chieftaincy hierarchy.

The Chieftaincy's function of entitling for national unity: Conferring of honorary chieftaincy titles on figures of national prominence 'in appreciation of the recipient's service to the community' promotes national unity. Such entitlement confers local legitimacy on national personalities. It also reinforces local community's or region's sense of belonging to the wider nation, which the honouree represents either formally or informally. Bestowing governing commemorative medals to model citizens including chiefs (even by universities) is widely acknowledged for its nation building symbolism (Esman, 1988 and Miles, 1993).

Traditional rulers are keepers of the peace function: Chieftaincy helps national governments in maintaining law and order outside the capital and other main cities, that is in the rural, otherwise such governments would be hard pressed. Police forces are often severely understaffed and lacking in popular support. Access to regular courts is often limited, local chiefs are indispensable in resolving low-level conflicts, which would overwhelm meagre police and judicial resources. Chieftaincy serve an invaluable role as conflict gatekeepers, prioritizing problems and deciding which ones do require outside, higher-level restraint adjudication. At times chiefs' jurisdiction vis-à-vis the police may need to be resolved especially on religious and customary disputes. Without chieftaincy hyper litigation and an overtaxing of formal legal institutions would be (Miles, 1993). 
Chieftaincy helps with the function of tax assessment and taxation: Where chieftaincy advisory or assessing role as chieftaincy has intimate knowledge of constituent's taxability. Where chieftaincy was used as or associated with fiscal oppression or usurpation, overall legitimacy becomes in jeopardy. Specialized local government services must bear the responsibility of tax collection (Miles, 1993).

Functions of the Chief as Ombudsman: Chiefs have historically served as societal ombudsman in centralized, diffused, and segmented systems. Though this needs to be formalized and upgraded, it still continues. Ombudsman function needs to be distinguished from judicial one; it implies formality and sanction imposition while judicial is not. It also needs formal training and systematic modernization. But ombudsmanchieftaincy needs to be kept divorced from partisan politics and undue administrative interference. The constitution needs to promote it (Esman, 1988 and Miles, 1993).

The function of solidarity safety valve by chieftaincy: The most important tangible function of chieftaincy is serving as a symbol of community solidarity (i.e. 'father' or 'mother' of the people). 'Chieftaincy is an institution in which the African... places his trust. His legal and constitutional horizon... reaches as far as his chief, but not to his capital. For many Africans the chief is still the personification of the moral and political order, protection against injustice, evil and calamity (Emile, Rouveroy \& Nieuwaal, 1987:23)'. The institutional importance of chieftaincy as a second level of legitimacy may not be underestimated. Public agencies simply become overextended, overcommitted and overwhelmed and chieftaincy offers a second tier of dual authority that is safety valve, safety net when formal political and social institutions fail because administration functions smoothly only when les is expected of it. Criticism against traditional rulers assumes them ignorant, illiterate and backward and retaining them holds back progress and development. However, chiefs are part of the learning modern society and are part of wider political business competent elite. The educated ones actually find themselves under-utilized. Furthermore, the educated ones are usually more relevant to the new dynamic development challenges. As such, chieftaincy may not be anachronistic. It needs to be contemporary, knowledgeable, legitimate, customary, communication-channel readily available, be parallel to the government structures, and respond positively to the changes for maintaining relevance in development initiatives (Esman, 1988 and Miles, 1993).

The Relations between the Democratic Local Authorities and Chieftaincy in Lesotho: This portion will be dealt with through the historical and the contemporary perspective. Historically, it can be reiterated that in the pre-colonial era, Basotho had no experience of popularly elected democratic local authorities. All powers were vested with chiefs assisted by advisors. Chieftaincy administered the tribal territory for the welfare and good governance of society. The tribe was consulted on decisions made and developmental issues affecting their communities through 'lipitso'/public meetings. Then during the colonial period, District Commissioners were introduced and took over most of the administrative powers of the chiefs. The central government established a local National Treasury into which revenues through fines imposed for example on stray animals, 'matsema' levy/levy on working schemes/groups, and others were paid. This arrangement denied and deprived chiefs of resources to undertake development activities of any significance. The District Commissioners also reduced the number of chiefs through the system of 'gazetting' chiefs. That is considering a chief to be one only on the length of service as a chief and the size of the population of his tribe (GOL, Reports, 1995). Nonetheless, before independence, a form of local government was introduced by the colonial government in 1959 with the establishment of District Councils. The people elected these and their functions included overseeing agricultural, commercial, educational and other developments at the local level. The Principal Chiefs were the presidents of these District Councils. Though still subject to some measure of central control, these bodies encouraged popular participation at the local level and were instrumental in the economic development of the country. The District Councils received a certain though inadequate amount of money from the central government. This structure of local government is the one that was abolished in 1968 by the Basotho National Party government that perceived itself not deserving to coexist with the democratic local government institutions dominated by membership of an opposition party, the Basotho Congress Party (GoL Reports, 1995).

The contemporary perspective on relations between democratic local authorities and chieftaincy may begin after independence. This is the period when the Chieftainship Act No. 22 of 1968 was introduced to regulate the administration of chiefs, their discipline, duties and powers. The Principal Chief recommended to the 
minister the gazetting and appointment of a chief. Chiefs' functions remained the same that was the good governance of their territories and land allocation, until the latter functions was revoked with the establishment of Development Councils. The military regime resuscitated Local Authorities in 1986 in the form of Development Councils at village, ward and district levels. Village Development Councils have thus incidentally been in every village with a gazetted chief and the term of office of members used to be three years. The chief soon lost the legal power to be the automatic official chairman but had to be elected to be the chairperson or remain then as an ex-officio member. The Basotho National Party legacy (1970-1985 dictatorship) used to put a chief as an automatic chairman but when the military regime (toppling Basotho National Party in 1986) critical of chieftaincy somehow, stripped them of such legal power to making them ex-officio members. Chieftaincy was being blamed for widespread corruption and suppression. The chairman of the Village Development Council (VDCs) was elected by members. VDCs' functions were to promote development and community participation in development projects and to allocate land. The Ward Development Council acted as a link between the VDCs and the District Development Council, collating projects from the former and communicating them to the latter. The District Development Council considered projects and promoted development for the general welfare of the people in that district. It was supposed to control a development fund and derived revenue from grazing fees but Basotho resisted this effectively to its failure stating that the military regime never created enough jobs or improved any pastures to impose grazing fees/tax. The central government paid sitting allowances to members of Ward Development Councils and District Development Councils while VDCs were voluntary. Reportedly, there were 8,000 VDCs, 24 Ward Development Councils and 10 District Development Councils. These bodies were largely ineffective and their caliber of membership personnel in terms of competency, quality, qualifications and skills left much to be desired. They could therefore as structures not be maintained as they were in the then to be the new incoming Local Government of 1997/98 (GoL Reports, 1993, 1997, 1998 and 2004). The chieftaincy also promoted development projects, acted as a link between the central government and the community and are still responsible for the maintenance of law and order. They shared the responsibility of land allocation with their Village Development Councils as ex-officio members. Chiefs are still being blamed for corruption of backdating land allocations to periods when they were only legally entitled to doing so to get bribes. This used to create a conflict between the Councils and chiefs who wanted to continue operating illegally and frustrate the task of land allocation by the Councils (GoL Reports, 1997 and 1998).

The Role of Chieftaincy and its constraints in the decentralized system of Lesotho: The role of chieftaincy in Lesotho has already been examined repeatedly. The shortcomings of chieftaincy are also historically known. However, it has been accommodated in the latest adopted local governance mainly for an advisory role and for the sake of maintaining peace and stability, both locally and nationally. There is a recorded strong feeling that Lesotho has reached historically a point of pure democracy and that the will of the people must be respected including allowing them to elect all forms of their leadership. Chiefs and the Basotho National Party are not for this ideology. Incorporation of chieftaincy into this new local governance is meant to harmonize traditional structures with the modern democratic systems so that there is no parallel structure to democratic local government (GoL Reports, 1997 and 1998). As such new administrative geographical boundaries for including chiefs had to be done with also the purpose of ease of access and communications infrastructure, human geography and population features and economic activities and resource base. The College of Chiefs (22 principal chiefs) has the responsibility of selecting chiefs to serve in the capacity of ex-officio members in the new local authorities. There is still a big challenge on how to integrate traditional authorities into the democratic system of local governance as the two are viewed to be incompatible. The College of Chiefs is still given the responsibility of finding out how best to incorporate chieftaincy in the new local governance and democracy (GoL Reports, 1995 and 1997).

Chieftaincy perceives itself as non-partisan to political parties and thus appropriate for facilitating and delivering services and development in a just manner while Local Authorities are biased officials representing only a particular political party's interests and are therefore likely going to distribute development benefits, information and opportunities along political inclinations. The chiefs see themselves to be more legitimate than the party representatives and represent the entire communities and not its parts. Local Authorities view chiefs as political affiliates to the BNP, having no public mandate as they are not elected representatives and not answerable to anyone. Some ordinary people still perceive chiefs as custodians of law and security providers to the vulnerable community sectors like the widows, orphans and so on at village level. Chiefs still 
reduce hyper litigation in that they preside and judge over 'petty' offenses and pass serious criminal offenses to courts of law or the police for action. They are thus seen as the extension of the devolved customary judiciary for peace and stability maintenance. Chieftaincy sees itself as representing the identity of the people of Lesotho including the politicians and that democracy is an imported system alien to the people.

It is necessary to have the right institutional arrangements and a clear line between administrative and developmental responsibilities if decentralization is to succeed in Lesotho. The chieftaincy opposing decentralization comprises almost the entire membership of the Senate house. This institutional arrangement poses a retarding effect on the process and efforts of decentralization. It somehow empowers traditional opposition against democracy. Hence the continuity of the tug-of-war between the Parliament (elected 'subjects') and the senate (appointed 'royals') in terms of power, roles and functions. The parliament has managed to influence local personnel, Local Authorities and some chiefs of the importance of decentralization. Furthermore, local administration is still greatly effected through chieftaincy while development issues are left for the councilors at the community level, urban boards in urban areas and district level and the Maseru City Councils as the municipal established in 1983 for the capital city only. This optimistic tendency of self-competing or unclear division of power between the opposing institutions in action has maintained chieftaincy well against decentralization for decades in the form of the dictatorial ruling and opposing Basotho National Party, Senators (law-making/approving structure) and grass root administrators. At some point, they have been automatic chairpersons of Village Development Councils, before 1994 during the military rule of 1986 . They have also become ex-officio members of the councils. Unfortunately, integrating them anyhow has maintained them as a formidable force opposing the smooth operation of decentralized governance. In defiance of the law of decentralization chiefs continued to allocate land because they felt stripped of 'birth' powers to rule and perform their duties. This created tensions between chieftaincy and the Ministry of Local Government overseeing decentralization. The ministry took many of them to court and was found guilty. This tended to belittle chiefs further as they form part of the customary judiciary. Chiefs find decentralization to be a mechanism of allowing unworthy 'commoners' to rule them as the worthy royal clergy/elite. The tug-of-war of competition over control and power has actually affected some development initiatives at the local, district and urban level. The central government is not able to intervene except where clear human rights have been offended. In cases where the government intervened, it uses arbitration when it is supposed to promote citizen diplomacy so that communities can solve their own problems. Exerting authority by local councils is also put under check by the territorial boundaries demarcated according to chiefs' wards that resist the new authority of local governance. The power, responsibilities and functions or roles and activities still allocated to chieftaincy and local authorities has and can continue to frustrate all development efforts at the local levels (GoL Reports, 1997 and Shale, 2004).

The society fears that political struggle between chieftaincy and local authorities may escalate. Most of the functions of the local authorities to be discussed later here are by themselves causes of conflictual power struggle as some of them have been traditionally the domain of the chiefs. The chiefs fear the loss of the functions and power to local authorities. They therefore attempt to cling to power by illegally continuing to perform such tasks and frustrate local authorities' efforts by non-cooperation in community mobilization in which they are essential. The functions of the local authorities are also limited still leaving a need for the central government to keep on performing other functions not done by the councils due to lacking in capacity. The decentralization law of Lesotho does not clearly indicate the implications of the decentralized functions in terms of how the local authorities will relate to their central government in implementing such functions. It simply states that local authorities will control natural resources and environmental protection without differentiating different types of natural resources stipulating ones to remain with the central government. Confusion and duplication of efforts thus happen to be incidental where the central government repeats the tasks performed by authorities in a locality. Spelling out how the various sectors of the central government will relate and be involved at the local level has become critically needed to prevent confusion and duplication of efforts. The central government needs to also be clear and decisive on the definite allocation of powers on administrative and developmental roles competed for by the chieftaincy and the local authorities. The challenge is how do local authorities mobilize and maintain peoples' participation, plan and implement development without the administrative or leadership power. At times for development to take place as already indicated, it may require both soft and hard approaches. This is intrinsically valuable from the thrust 
of Lesotho's decentralization purported to promote socio-economic welfare of all citizens aiming at service delivery and good governance/popular participation. This service delivery/development and good local governance comprise objectives and roles and functions already indicated and set within the 1997 Local Government Act and 1998 Government Elections Act on local authorities elections. They encompass objectives such as to provide for good governance, ownership and accountability in matters of public policy. Facilitate democratic control over the development planning process, -to move decision-making, resource allocation and local level development planning into the hands of the people, -to provide for the equitable distribution of human, institutional, infrastructural and financial resources across the country. To enhance the effectiveness of developmental activities by creating opportunities for elimination or reduction of duplication in development efforts, - to facilitate sustainability through matching development decision with local conditions, - to facilitate greater speed and flexibility of decision making as a result of reduced central direction and control, - and to facilitate mobilization and maximization of local resources, technologies and skill. Besides these objectives, the roles and functions of the local authorities include; control of natural resources and environmental protection, public health, land/site allocation, grazing control, allocation of burial grounds, and control of building permits. Local administration of central regulations and licenses, care of mothers, young children, the aged and integration of people with disabilities, mortuaries, burial of bodies of destitute persons and unclaimed bodies and forestry preservation and improvement of designated forests in local authority areas (Ministry of Local Government/MLG, 2003:2 and Shale, 2004).

\section{Conclusion}

This desk study has reviewed the validity of an argument justifying the role of the traditional rule or chieftaincy in the modern 'decentralized governance for development' (DGD) or decentralization in Lesotho. It has the role of traditional chieftaincy in the modern era of Lesotho's democracy/DGD and the function of traditional chieftaincy and its nature of relations with the democratic local authorities and constraints in DGD in Lesotho. The article discussed chieftaincy and colonialism in Lesotho, institutional roles of chieftaincy in Lesotho, the role of chieftaincy in the era of democracy/DGD in Lesotho, nature of relations between the democratic local authorities and chieftaincy in Lesotho and the role of chieftaincy and its constraints in the decentralized system of Lesotho. The paper has successfully demonstrated that chieftaincy is needed in modern DGD to play the linkage role, entitling for national unity role, function as peacekeepers, help with the function of tax assessment and taxation and function as ombudsmen and solidarity safety valve.

\section{References}

Emile, A. B., Rouveroy, V. \& Nieuwaal, V. (1987). Chiefs and African States. Journal of Legal Pluralism and Unofficial Law, 25/26, 1-46.

Esman, M. J. (1988).The maturing of development administration. Public administration and development, $8(2), 125-139$.

GOL. (1998). Government Gazette. Lesotho: Government Printing Unit.

GoL/Government of Lesotho. (1995 and 1999). Annual Reports, MOET/Ministry of Education and Training. Maseru Lesotho: GoL Printers.

Government of Lesotho. (1997). The Report on the Land Policy Review. Maseru: Government Printer.

Government of Lesotho/GoL. (1998). National Co-operative Policy. Maseru: GOL.

Government of Lesotho/GoL. (1999). National Livestock Development Study: Farmers Consultative Forum. Phase 1 Report, Part II. Maseru: Kingdom of Lesotho.

Government of Lesotho. (1999). Ministry of Agriculture Report. Maseru: Government Printing Unit.

Lesotho Government/GoL. (1997). Local Government Act No. 6 1997. Maseru: Government Printers.

Lesotho Local Development Programme Concept Paper. (2004). Maseru: GoL Printers.

Miles, W. F. S. (1993). Traditional Rulers and Development Administration in Niger, Nigeria and Vanuanu. Studies in Comparative International Development, 28(3), 31 - 51.

Ministry of Local Government. (1996 and 2003). White Paper: Rural and Urban Development. The Establishment of Democratic Local Government. Maseru: GOL.

Shale V. R. (2004). Decentralization, Development and Conflict, Challenges Awaiting Local Authorities in Lesotho. EISA Occasional paper, No 21, June 2004.

The Constitution of Lesotho. (1993). Government of Lesotho. Maseru: GoL Press. 